\title{
'QUALITY' ADVICE FROM FRENCH PREVENTIVE ARCHAEOLOGY
}

Nathan Schlanger \& Kai Salas Rossenbach

In their lucid and thought-provoking paper, Carolina Andersson, Agneta Lagerlöf and Eva Skyllberg clearly identify the looming quandary of contemporary archaeology: how can we promote our professional concerns with scientific and patrimonial 'quality' in a context increasingly dominated by (often short-term) economic and political considerations? Almost twenty years have passed since the Valletta Convention called for the reconciliation of archaeology and spatial planning $\left(\mathrm{CoE}\right.$ treaty $\mathrm{n}^{\circ} \mathrm{I} 43$, I992), but some European countries still remain ambivalent or uncertain regarding the systems they have chosen to implement. In terms of their overall policies on archaeological heritage management, Sweden and France are both clearly on the 'public service' end of the spectrum, where the state is expected to take responsibility over threatened archaeological remains and then control the quality of their protection and study (cf. Demoule 2002; Demoule 2010; Willems \& Van den Dries 2007:I0; Kristiansen 2009:643 ff). Given these affinities, some recent experiences in French archaeology can well serve as examples - or indeed as cautionary tales - for the unfolding situation in Sweden.

A brief terminological excursus will clear the way, insofar as both Swedish and French can offer some linguistic depths vis-à-vis the lingua franca. In the critical spirit of this paper, the casual expression 'development-led archaeology' appears difficult to uphold. It builds on an ambiguity in the English language between a wide-ranging and noble notion of development ('sustainable', 'social', 'cultural') and the more 
down-to-earth realities of infrastructure and building works (bulldozers, surveyors, gravels and tarmacs). Clearly, the archaeology called for by the Valletta Convention can hardly be said to be 'led' by some positive developments, as much as funded, following the polluter pays principle, by the building contractors, i.e. developers, concerned. Our respective mother tongues prove here more subtle: the Swedish $u p p$ drag (as in uppdragsarkeologi) translates as 'commission' or 'assignment', while the French archéologie préventive can well be rendered as preventive archaeology, in the mode of preventive medicine or preventive detention (to prevent archaeological remains from being destroyed without study). In this sense, the archaeology that is 'commissioned' or 'preventive' can have as its counterpart the archaeology that is 'programmed' or 'initiated' on unthreatened sites (rather than the expression 'research-led', which implies that the 'developer-led' is bereft of research considerations). Overall, these notions can serve us to place the 'lead' on quality where it squarely belongs: not with the building contractors, but rather with the archaeological operators, prescribers and regulators.

As we know, measures to ensure that 'commissioned' archaeological work remains of high quality in scientific and patrimonial terms vary considerably from country to country, in the light of different traditions of governance, spatial planning, legislation, academic norms, professional standards, and so on (see recent overviews in D'Andrea \& Guermandi 2008; Bozoki-Ernyey 2007; Demoule 2007; World Archaeology 4I/4, 2009; Schlanger \& Aitchison 2010). So far as France is concerned, the long awaited heritage law of $200 \mathrm{I}$ emphasizes that (in paraphrase) preventive archaeology is a mission of public service governed by the principles of scientific research, which seeks to identify, safeguard, study, interpret and widely disseminate results pertaining to threatened archaeological remains (for recent developments in French archaeology see Demoule \& Landes 2009; Giraud 20 I0; Schlanger \& Salas Rossenbach 20I0) This 200 I law also brought about the creation of INRAP, transforming and expanding a pre-existing association into a national research institute, with now over I 800 archaeologists. In operational and administrative terms, a clear distinction was formalised between an evaluation or diagnostic phase, where previously unrecorded archaeological remains are identified on land slated for development (mainly through systematic trial trenching), and an excavation phase, which focuses on the remains deemed worthy of scientific 
recording and study. Both phases are undertaken upon prescription by the Ministry of Culture (SRA) and with the control of research designs, results and publications through regional and national archaeological bodies (CIRA, CNRA), composed of experts from universities, CNRS, INRAP, local authorities and the Ministry of Culture.

Then came 2003 and the law changed again, following a certain ideological reorientation exacerbated by pressures from developers and local representatives, frustrated by barriers to archaeological recruitments and other delays. The ensuing modifications have their direct impact on questions of quality:

- First, while the diagnostic phase is still considered a public service to be undertaken by INRAP and other authorised public bodies (with funding through a dedicated tax per square meter), the excavation phase has been formally opened to commercial tendering.

- Next, responsibility for commissioning archaeological excavations (as prescribed by the Ministry) now rests completely with the developers. Public developers can themselves set the relative weight they accord in their calls-for-tender to such factors as cost, time, or scientific quality, while private developers have no obligation at all to tender and can choose any operator at will. While a series of scientific requirements are laid out by the prescriber, it is only as a fait accompli, once the contract between developer and operator has been signed, that the state can gain a modicum of vision into the pertinence and the feasibility of the proposed research design.

- Last but not least, a licensing system for operators of preventive archaeology has been introduced. The procedure for its granting includes information on the functional offer of the candidate unit, the quantity and quality of their human resources, their budgets, infrastructures, equipment and so forth. As awarded by the Ministry of Culture, the licence can include territorial and chronological restrictions, and activities of diagnostics remain limited to public bodies. By mid 20I0, there were in France 80 licensed operators: 60 local authorities and public bodies, and 20 private companies.

Altogether, these licensed operators now undertake something like $40 \%$ of the preventive excavations in France, and this 'market' appears set to grow. On the one hand, there is increasing pressure from developers to hasten procedures and clear the grounds, including a call 
to change the rules and grant licences (including for diagnostics) to private operators specifically created by quarrying and building companies. On the other hand, some state administrations seem to exhibit a belated excess of neoliberal zeal, enticing prescribers and controllers to relax standards and unduly encourage competition. Whether this competition is really time- and cost-reducing remains to be seen, but there is no doubt that its effects on quality are detrimental. When the current tendency - exacerbated by the global economic crisis - is for archaeological operations to become predominantly commercial transactions, rendered to the satisfaction of the developer-customer with minimal analyses or publications, there is a real risk that also scientific information or research methodologies will become commercial assets or 'patents' in their own right, to be withheld from erstwhile colleagues and now rival archaeologists for the sake of some lucrative contracts, rather than shared and developed together towards an increased understanding of the past. The situation in France is not irreversible, far from it, but if there is one piece of 'quality' advice we may offer here it is to ensure that the state, its prescribers, experts and regulators are enabled and encouraged - and goaded if need be - to fulfil their roles as guardians of a quality-led archaeology, in the spirit and the letter of the Valletta Convention. 


\section{References}

Bozoki-Ernyey K. (Ed.) 2007. European preventive archaeology: papers of the EPAC Meeting, Vilnius 2004. Budapest: National Office of Cultural Heritage, Hungary - Council of Europe.

D'Andrea A. \& Guermandi M.P.(Eds) 2008. Strumentiper l'archeologie preventiva, Esperienze, Normative, Tecnologie. Budapest: $\mathrm{EPOCH} /$ Archaeolingua.

Demoule J.-P. 2002. Rescue archaeology: the French way. Public Archaeology, vol 2, pp $170-7$.

Demoule J-P. (Ed.) 2007. L'archéologie préventive dans le monde, Apports de l'archéologie préventive à la connaissance du passé. Paris: La Découverte.

Demoule J-P. 20IO. The crisis - economic, ideological and archaeological. In Schlanger N. \& Aitchison K. (Eds). Archaeology and the global economic crisis. Multiple impacts, possible solutions. Brussels: ACE/CultureLab.

Demoule J-P. \& Landes C. (Eds) 2009. La fabrique de l'archéologie en France. Paris: La Découverte.

Giraud J-P. 20IO. Organisation et structure de l'archéologie française. Archäologisches Nachrichtenblatt, vol I 5/2, pp I 50-I6I.

Kristiansen, K. 2009. Contract archaeology in Europe: an experiment in diversity. World Archaeology, vol 4I/4, pp 64I-648.

Schlanger N. \& Salas Rossenbach K. 20I0. One crisis too many? French archaeology between reforms and re-launch. In Schlanger N. \& Aitchison K. (Eds). Archaeology and the global economic crisis. Multiple impacts, possible solutions. Brussels: ACE/CultureLab.

Schlanger N. \& Aitchison K. (Eds) 2010. Archaeology and the global economic crisis. Multiple impacts, possible solutions. Brussels: ACE/CultureLab.

Willems W. \& Van den Dries M. 2007. The origins and development of quality control in archaeology. In: Willems W. \& Van den Dries (Eds), Quality Management in Archaeology. Pp. I-I 2. Oxford: Oxbow Books.

World Archaeology, vol 4I, issue 4, 2009. London: Routledge. 